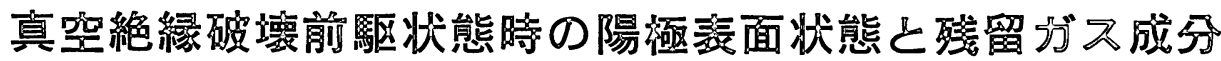

\author{
小林 信一・鈴 木 健 司 - 勝部 昭 明 - 仲江川 知 秀* \\ 埼玉大学工学部 $\overline{\mathbf{T}} 338$ 浦和市下大久保 255
}

(1988 年 5 月 6 日 受理)

\section{Changes in Components of Residual Gases and Conditions of Electron Bombarded Surface during Prebreakdown Situation in a Vacuum Gap}

\author{
Shin-ichi KOBAYASHI, Kenji SUZUKI, Teruaki KATSUBE \\ and Tomohide NAKAEGAWA
}

Faculty of Engineering, Saitama University

255 Shimo-Ohkubo, Urawa-shi, Saitama 338

(Received May 6, 1988)

\begin{abstract}
Gas liberation from electron-bombarded electrode surface during prebreakdown situation is one of important factors that cause electrical breakdown in a vacuum gap. Changes in residual gas components were monitored with a quadrupole mass specrometer, and electron-bombarded electrode surfaces were analyzed with an X-ray photoelectron spectrometer. The ions formed in the prebreakdown gap were also analyzed by a time of flight mass spectrometer installed in a prebreakdown measurement apparatus. It was found that the residual gas components in the prebreakdown situation are $\mathrm{H}, \mathrm{H}_{2}, \mathrm{H}_{2} \mathrm{O}, \mathrm{CO}$, and $\mathrm{CO}_{2}$, and the mass numbers of the carriers formed in the vacuum gap were the same as those of the residual gas components. The reaction of the electron bombarded surface and the effect of the reaction on vacuum breakdown phenomena are also discussed.
\end{abstract}

\section{1.まえがき}

真空の絶縁破壊が，電極表面からの中性粒子あるいは 荷電粒子の放出により発生することは広く認められてい る1,2)。絶縁破壊には，何の前触れむなく突如として発生 する場合と，破壊直前に微小な電流が流れた後破壊が発 生する場合とがある。前者は，電極表面に緩く付着して いたマクロ粒子（クランプ）によるむのといわれ3゙，比 較的高電圧の場合飞生ずる。乙の場合，破壊の予測は困 難である。それに対して, 後者は, 破壊直前に電流（絶 縁破壊前駆電流）が流れるため, 破壊の予測が可能であ ると共に，電流の発生原因及びそれに及ぼす物理的，化 学的過程を調べるととにより, 破壊過程の解明並びに絶 縁耐力の向上を図るととができる可能性がある。そのた め, 前駆電流についててれまで多数の研究がなされてき

* 現在: 三菱金属株式会社 $\overline{\mathbf{T}} 100$ 千代田区大手町 1-5-2

$$
\text { ている }{ }^{4,5)} \text { 。 }
$$

この電流は大部分が電界放射による電子電流であり, 従って, 陰極表面状態が現象の支配要因である。しかし ながら，定常的に電圧が印加されている真空ギャップの 場合, 陽極表面は常に電子照射に曝されている状態にあ る。その結果, 陽極表面状態は電子照射の間に変化する こ之が考えられる。更に，乙の表面状態変化の間に陽極 から放出される脱離生成物は, 真空容器内に拡散すると 同時に陰極表面に堆積して電子放射特性に変化を生じさ せる可能性がある ${ }^{6)}$ 。

筆者等は, 以前に真空絶縁破壊前駆電流特性に対する 陽極表面状態の影響を調べ報告した ${ }^{7)}$ 。そてでは，陽極 で生成されるイオン成分と表面状態変化を測定し, 前駆 電流特性に及ぼす効果について述べた。しかしながら， 電子照射により発生すると考えられる中性ガスについて は言及されていなかった。今回, 陽極で発生するイオン 成分を同定すると共に，陽極面で電子照射により生ずる 


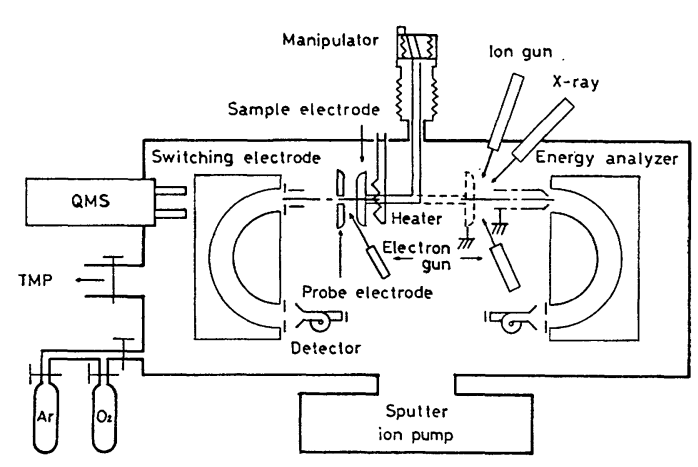

Fig. 1 Schematic representation of experimental apparatus.

中性ガスを分析するために，残留ガス分析用に 4 重極質 量分析器を導入した。また, 電子照射による効果をより 明確にするために，電子銃を用い試料電極（即ち陽極） に電子を照射して同様に発生する残留ガスの分析む行っ た。同時に，これらの電子照射による表面状態変化をX 線光電子分光法により分析した。本論文では, その結果 について報告する。

\section{2. 実験装置・方法}

上で述べたように，真空の絶縁破壊前駆現象は表面状 態に敏感であるため, 各種の分析及び測定が同一真空中 で可能 (in-situ 測定) である必要がある。Fig. 1 亿実 験装置の概要を示す。基本的には既報 ${ }^{8)}$ のあと同一で あり，そこに 4 重極質量分析計 (QMS), 試料電極（陽 極）照射用電子銃が追加されたものである。同一真空容 器内に, 真空絶縁破壊前駆現象を測定する部分（同図左 側), 試料電極表面の処理, 分析並びに電子照射を行う 部分（同図右側）が設けられており，in-situ 測定を可 能としている。

これらの測定, 分析の選択は中央部のマニピュレータ により試料電極を回転させて行う。本研究のような表面 現象を扱う実験では，電極の表面処理，排気の方法，測 定手順により得られる結果に大きな相違を生ずることが ある。そこで，以下では装置各部及び実験方法について 詳しく述べる。

\section{1 真空絶縁破壊前駆現象測定部}

Fig. 1 の左侧に試料電極を位置させることにより, 前 駆現象の测定を行うことができる。キャリア取り出し用 のプローブ電極に試料電極を対向させて真空ギャップを 構成し (ギャップ長 $0.1 \mathrm{~mm}$ ), 直流高電圧 $(3 \mathrm{kV} \max )$ を印加して破壊前駆状態を形成する。これにより，極間 には破壊前駆電流が定常的に流れ，陽極からイオンが発 生する。
試料電極には正の高電圧が印加され，プローブ電極は 接地電位であることから, 陽極で発生したイオンは, プ ローブ孔を通過して分析部に入射する。プローブ電極に は， $0.3 \mathrm{~mm} \phi$ のプローブ孔が 5 個設けられている。

分析部では, イオンのエネルギ及び質量の分析を行 う。エネルギ分析器には同図に示されるような同心半球 型を用いている。軌道半径は $50 \mathrm{~mm}$ であり, 偏向電圧 を掃引することによりエネルギ分布を得ている。

スイッチング電極, エネルギ分析器及び検出器によ り, 飛行時間型の質量分析器が構成されている。通常, スイッチング電極には偏向電圧が印加され，イオンの通 過が制限されている。乙の電圧を $0 \mathrm{~V}$ とした瞬間から 検出器で信号が検出されるまでの時間を計測し, イオン のエネルギを考慮することにより，イオンの質量を決定 するととができる。実際の質量分析の手法は，エネルギ 分析器の形式及びスイッチング電極の位置が異なること を除けば， 既報9”のあのと同一である。

\section{2 表面処理及び分析部}

同図に示される右側では，電極表面の処理及び分析を 行う。電極の表面処理は, Ar イオンスパッタによる清 浄化及び試料電極の加熱酸化である。乙れらを目的によ り使い分ける。

表面分析にはX線光電子分光法 (XPS) を用いた。乙 れは，表面を非破壊的に分析できること，化学状態の分 析む可能であることによる。X線源には $\mathrm{Mg}$ 陽極のも のを用いている。エネルギ分析器には，絶縁破壊前駆状 態時の分析に用いたものと同様な軌道半径 $50 \mathrm{~mm}$ の同 心半球型を使用している。乙の場合のエネルギ分布の測 定には, エネルギ分解能が原理的に変化しない減速電位 掃引法 ${ }^{10)}$ を採用した。

XPS は, 光源としてX線を使用するため分析領域を 局所化することができず，本研究のような荷電粒子照射 を受けた狭い領域を分析するのは困難なととが多い。し かしながら，荷電粒子照射による表面状態変化を分析す るにはXPS の応用が最適である。XPS において分析領 域を局所化する手法には，入射レンズによるあの，照射 X線を絞るあの，スリットを小さくするもの等いくつか の方法がある。ここでは真空容器の大きさの点から, スリットを小さくすることにより目的を達している。入 射スリット及び出射スリット径は $1.0 \mathrm{~mm}$ であり，レン ズの倍率は 1 倍としてあるので分析, 領域は約 $1.0 \mathrm{~mm} \phi$ と見積あられる。このように，スリット径が小さいため に，感度が市販品に比較してかなり低いむのとなってい るが，分析時間を長くするととにより対処している。

以上のような分析器の幾何学的構成から, 分解能は 1. $0 \%$ であり, 通過エネルギを $200 \mathrm{eV}$ としたととによ 
りエネルギ分解能は $2 \mathrm{eV}$ となる。

\section{3 真空排気系}

以上の各装置は, 容積約 $40 l$ のステンレス鋼製の真 空容器に収められている。乙の容器には, 電極清浄化用 の $\mathrm{Ar}$ ガス (純度 $99.995 \%$ ) 及び酸化処理用の $\mathrm{O}_{2}$ ガ ス（純度 99.99\%）導入用の配管がなされている。

排気は, ターボ分子ポンプにより粗引きしながら 150 ${ }^{\circ} \mathrm{C}$ で 60 時間ベーキングを行った後, イオンポンプとチ タンゲッタポンプにより行い, 到達圧力は $1 \times 10^{-7} \mathrm{~Pa}$ であった。

\section{4 実験方法}

試料電極には純度 $99.99 \%$ Al 及び $\mathrm{Cu}$ を用い, 真空容器に取り付ける前に, \#1200メッシュのエメリー

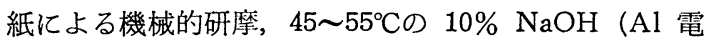
極) 溶液, $10 \sim 20 \% \mathrm{HNO}_{3}(\mathrm{Cu}$ 電極) 溶液による化学 的エッチング (電極表面の結晶粒が見えるようにする), メタノール中での超音波洗浄, の各処理が施された。更 に, 真空容器に取り付けた後, ベーキング中に 24 時 間, $500^{\circ} \mathrm{C}$ に加熱し十分なガス出しを行う。試料電極酸 化の方法は, 電極を $300^{\circ} \mathrm{C}$ に加熱し, 容器内に $\mathrm{O}_{2}$ を $0.1 \mathrm{~Pa}$ まで導入して行った。また, 清浄化処理には $\mathrm{Ar}$ イオンエッチングを行った。

以上の処理を施した電極を試料電極として陽極に用 い, プローブ電極には同一材質のものを使用した。プロ ーブ電極には電子銃による加熱脱ガス処理が施された。

前駆状態では, 発生イオン分析及び残留ガス分析を行 い, 陽極への電子照射を電界放射電子から電子銃に代え た場合にも同様に残留ガス分析を行う。これらの測定は 数〜10 時間に亘って行われ, その間の成分変化を調べ た。更に, 電子照射による表面状態変化を随時 XPS に より分析する。

飛行時間型質量分析装置, 前駆キャリアのエネルギ分 析及び XPS 装置のコントロール, データ収集処理は, パーソナルコンピュータを有するシステムコントロール により自動化されており, 実験能率の向上が図られてい る。

\section{3. 実験結荲及び検討}

\section{1 真空絶縁破壊前駆状態における発生イオン}

前駆状態において発生する正イオンの質量分布の一例 として, Al 電極清浄表面の場合の正イオンの質量分析 結果を Fig. 2 に示す。乙れらは, $3.00 \mathrm{keV}$ の運動エ ネルギを有する正イオンについて調べたものである。既 に筆者等が報告したように ${ }^{11)}$ ，前駆状態において発生す る正イオンは, ほぼ印加電圧に相当するエネルギを有す るあのが大部分である。そこで, ことであ印加電圧に相
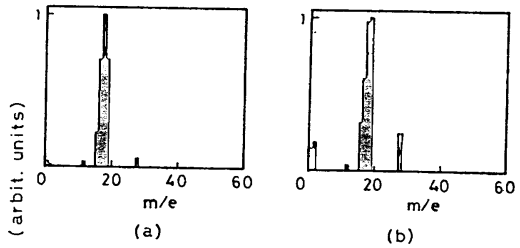

(b)

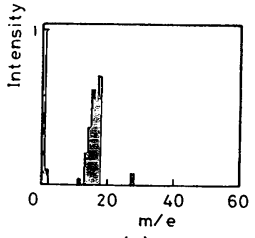

(c)

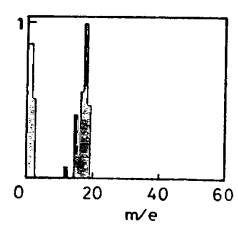

(d)

Fig. 2 Mass spectra of ions formed in the prebreakdown vacuum gap. Clean Al surface. Prebreakdown time: (a) $0 \mathrm{~h}$ (immediately after high voltage application), (b) $1 \mathrm{~h}$, (c) $4 \mathrm{~h}$, (d) $10 \mathrm{~h}$.

Table 1 Ion components formed in the prebreakdown vacuum gap.

\begin{tabular}{l|c|l}
\hline Surface & Material & \multicolumn{1}{|c}{ Ions } \\
\hline \multirow{2}{*}{ Clean } & $\mathrm{Cu}$ & $\mathrm{H}^{+}, \mathrm{H}_{2}{ }^{+}, \mathrm{CH}_{4}{ }^{+} / \mathrm{O}^{+}, \mathrm{H}_{2} \mathrm{O}^{+}$ \\
& $\mathrm{Al}$ & $\mathrm{H}^{+}, \mathrm{H}_{2}^{+}, \mathrm{CH}_{4}^{+} / \mathrm{O}^{+}, \mathrm{H}_{2} \mathrm{O}^{+}, \mathrm{CO}^{+}$ \\
\hline \multirow{2}{*}{ Oxidized } & $\mathrm{Cu}$ & $\mathrm{H}^{+}, \mathrm{H}_{2}^{+}, \mathrm{CH}_{4}{ }^{+} / \mathrm{O}^{+}, \mathrm{H}_{2} \mathrm{O}^{+}$ \\
& $\mathrm{Al}$ & $\mathrm{H}^{+}, \mathrm{H}_{2}{ }^{+}, \mathrm{CH}_{4}^{+} / \mathrm{O}^{+}, \mathrm{H}_{2} \mathrm{O}^{+}, \mathrm{CO}^{+}$ \\
\hline
\end{tabular}

当するイオンについて質量分析を行った。

これらの結果は，イオンの質量分布の経時的な変化を 示しており, 前駆状態開始直後, 1 時間後, 4 時間後及 び 10 時間後の分析結果を示している。それぞれ最大計 数值の質量数を基準にしてその計数值を比較した。

まず, 前駆状態開始直後及び 1 時間後では, $\mathrm{H}_{2} \mathrm{O}^{+}, の$ 割合が高いことが分かる。また，4時間以降になると $\mathrm{H}^{+}, \mathrm{H}_{2}{ }^{+}$の割合が高くなってきており, 前駆状態の時間 経過と共に発生イオン成分が変化することが示されてい る。しかしながら, 酸化された表面の場合は, このよう な変化は少なく, 一貫して $\mathrm{H}^{+}, \mathrm{H}_{2}{ }^{+}$が発生イオンの主 成分であった。乙のととは $\mathrm{Cu}$ 電極であ同様であった。

$\mathrm{Cu}$ 電極について行われた質量分析結果も合わせ, 前 駆状態で発生する正イオン成分をまとめて Table 1 に 示す。この結果から明らかなととは, 金属材料を含む正 イオン $\left(\mathrm{Cu}\right.$ 電極の場 合は $\mathrm{Cu}^{+}, \mathrm{CuO}^{+}, \mathrm{Cu}_{2} \mathrm{O}^{+}$等, $\mathrm{Al}$ 電極の場合は $\mathrm{Al}^{+}, \mathrm{Al}_{2} \mathrm{O}_{3}{ }^{+}$等) が認められず, 発生イ オンは残留ガス成分に一致していることである。この事 実は, これらの正イオン成分が電極表面に吸着し, その 
後, 前駆電流による電子衝撃の結果生じたあのであるこ とを表している。

更に, $\mathrm{Al}$ 電極の場合には, $\mathrm{CO}^{+}$も発生しているとと が示されている。残留ガス中の $\mathrm{CO}$ が電極へ吸着され 放出されたすのとすれば, $\mathrm{Al}$ 電極は $\mathrm{Cu}$ 電極に比較し て CO が吸着しやすいととになり，また，放出過程前に 何らかの作用，例えば電子照射により CO が生成され たすのとすれば, $\mathrm{Al}$ 電極は $\mathrm{Cu}$ 電極より電極上での反 応が起こりやすいことが推測される。一般に, CO は不 活性であり吸着し難いと考えられているととから, CO の生成は電極表面上での電子が介在した反応によるすの と考えるととができる。

以上のように，前駆状態に㧤いて発生する正イオンの 主成分は, $\mathrm{H}^{+}, \mathrm{H}_{2}{ }^{+}$及び $\mathrm{H}_{2} \mathrm{O}^{+}$であることから, 引き続 く絶縁破壊にはこれらのガスの挙動が大きな影響を及ぼ すことが予想される。また, 試料電極は十分なベーキング により脱ガス処理が施されているにあかかわらず $\mathrm{H}_{2} \mathrm{O}^{+}$ が主成分となっていることあ注目すべき点である。

\section{2 残留ガス成分}

破壊前駆状態において発生するイオンは残留ガス成分 に相当するすのであると考えられることが，前記実験で 判明した。そこで, 実際に残留ガス分析を行い, ギャッ プ中で発生するイオン成分と比較するとととした。

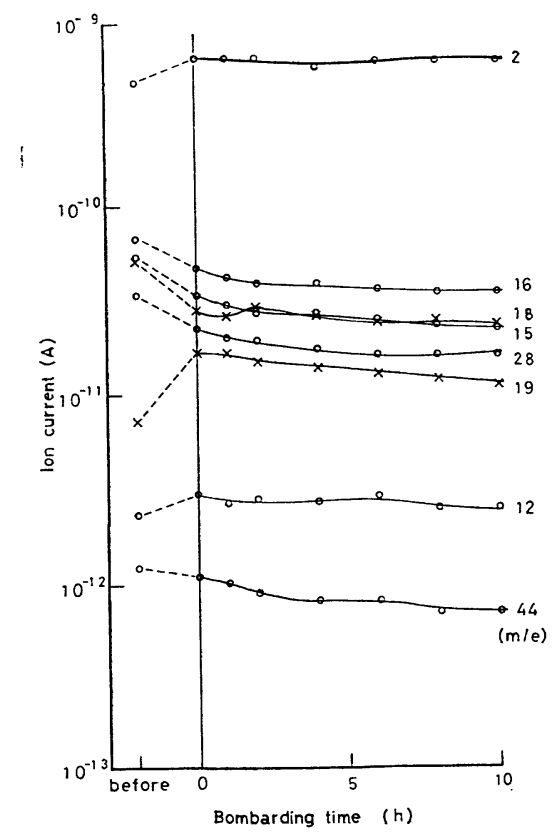

Fig. 3 Time dependence of the residual gas composition under prebreakdown electron bombardments on the anode of the vacuum gap.
ギャップが前駆状態下にあるときの残留ガス成分の時 間的変化を Fig. 3 に示す。乙れは, 清浄 Al 電極につ いての結果である。乙の図から, 残留ガスの分圧は, $m /$ $e=18,19$ を除き, 多い方から $m / e=2,16,15,28$, 44 の順であることがわかる。この順序は $\mathrm{Cu}$ 電極の場 合む同様であり，前駆状態前と同じであった。

ここで, 前駆状態以前と前駆状態開始直後のイオン電 流の変化を見てみると, $m / e=2,12,19$ を除いていず れむ減少している。特に, $m / e=18$ の減少は, 先のギャ ップ間で発生するイオンの主成分がやはり $m / e=18$ で あったことに対応するあので, 注目すべき結果である。

一方，乙こには示していないが， $\mathrm{Cu}$ 電極の場合， $m /$ $e=15,16,28$ は Al 電極とは異なり, 增加する結果が 得られた。陽極表面に残留ガスが吸着しており, それら が前駆電流の電子衝撃により脱離するとすれば，中性 ガス成分は真空容器内に拡散し, 前駆状態直後には残留 ガス分圧は上昇するととが考えられる。しかしながら ここに示した結果では, 前駆状態直後の残留ガス分圧の 変化に電極材料依存性のあることが示されている。従っ て, 真空ギャップのような電極配位の場合, 陽極からの ガスの脱離は上に述べたような単純なものではなく，表 面状態が関与した電子線との化学反応が影響を及ぼし いる屯の亡思われる。特に, A1 電極の場合に分圧の減 少が観測された $m / e=15,16,28$ は, $\mathrm{CH}_{4}(m / e=16)$, $\mathrm{CO}(m / e=28)$ が共にCを含むガスであることから，前 駆電流の電子成分により陽極表面に集積し，しかむ表面 上に長時間吸着しているためであると考えるととができ る。

次に, 前駆状態開始直後と前駆状態 10 時間維持後の

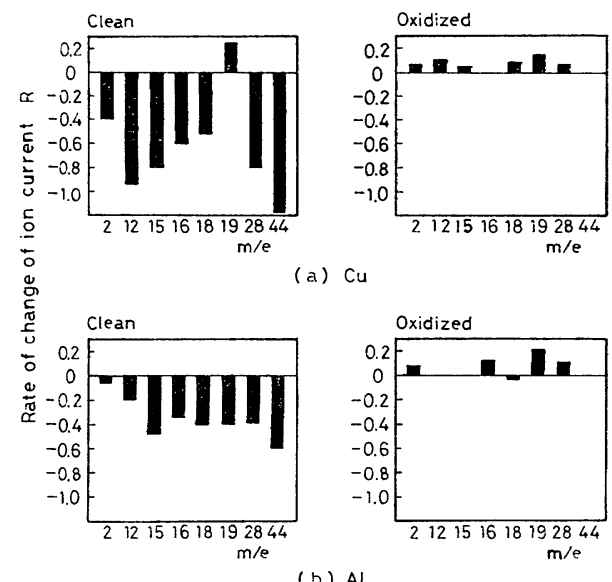

Fig. 4 Variation of the ion current measured by QMS. $R=\left(I-I_{0}\right) / I_{0}$, where $I_{0}$ : ion current at $t=0, I$ : ion current at $t=10 \mathrm{~h}$. 


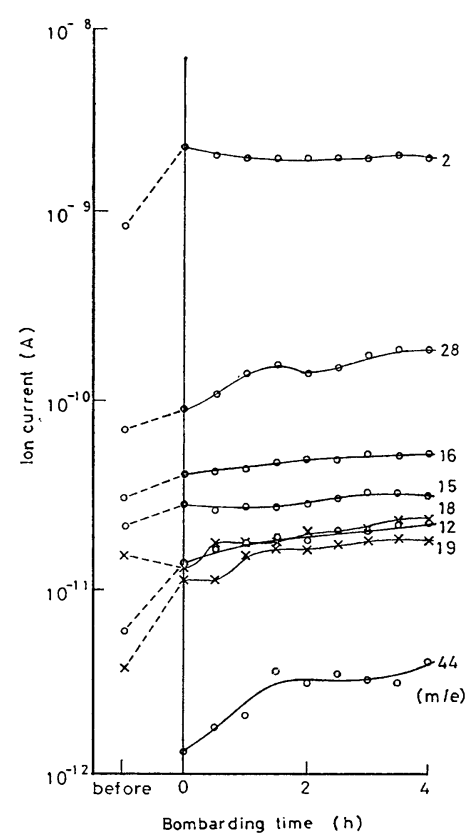

Fig. 5 Time dependence of the residual gas composition under electron bombardments by the electron gun.

イオン電流の変化率を Fig. 4 に示す。乙れは, Fig. 3 の前駆状態開始直後と 10 時間維持後のイオン電流の比 を，各電極材料及び表面状態についてまとめたものであ る。 $m / e=18,19$ を除いて, 清浄表面の場合, 前駆状態 開始直後に比べ 10 時間維持後にはいずれのイオンも減 少している。それに対して酸化表面の場合には，殆ど変 化がないか僅かに増加の傾向にある。

電極材料, 電極表面状態にかかわらず同様の特性とな っているが，ガス放出の過程はかなり異なっているもの と考えられる。何故ならば, 前述の前駆状態前と直後の ガス分圧を比較した結果によれば，ガス放出過程に相違 のあることが予想されるためである。

電子照射を前駆電流から電子銃に代えて残留ガス分析 を行った結果を Fig. 5 に示す。これによれば，分析対 象としたすべての成分が照射時間と共に増加する傾向に あるととがわかる。この場合は発生ガスは総て真空容器 内に拡散する。それに対して真空ギャップの場合は，陽 極で発生したガスは必ずしあすべて容器内に拡散するわ けではなく，ギャップ中に閉じ込められ，表面状態が関 与した複雑な反応を起てしていることが考えられ，てれ が残留ガス分圧の挙動に相違が見られる原因となったも のと思われる。

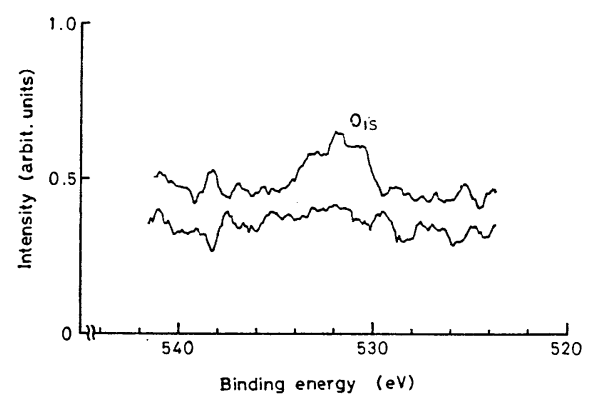

Fig. 6 Change in $\mathrm{O}_{1 \mathrm{~S}}$ line of the clean $\mathrm{Al}$ surface with prebreakdown electron bombardments.

\section{3 陽極表面状態}

これまでの実験結果から, 電子照射により, 吸着ガス の脱離, Cを含むガスや $\mathrm{H}_{2} \mathrm{O}$ の電極面への集積及びそ こでの異種ガスの生成, 放出, また, 清浄 $\mathrm{Cu}$ 電極ではこ の生成が生じないととが明らかとなった。従って, 陽極 表面上においててのような現象が起きているとすれば， 前駆状態前後での表面状態は異なっているはずである。

Fig. 6 に清浄 Al 電極に対する前駆状態前後での $\mathrm{O}_{1 \mathrm{~s}}$ スペクトルの変化を示す。前駆状態前では，表面は 清浄であり $\mathrm{O}_{1 \mathrm{~s}}$ のピークを認めることはできないが, 前 駆状態後ではわずかに○の存在を認めることができる。 $\mathrm{Cu}$ 電極の場合には，乙のような変化を認めることはで きなかった。

$\mathrm{Cu}$ 電極の場合にピークの変化が認められなかった理 由としては, 前駆状態によって表面が変化しなかったか, あるいは変化が極めて微弱なために分析不能であったて とによることが考えられる。特に，後者については，前 駆電流による照射領域が半径 $0.1 \mathrm{~mm}$ 程度と推定され るのに対して, XPS 装置の分析領域が局所化されたとは いえ直径約 $1 \mathrm{~mm}$ 程度であるため, 電子照射により変化 の生じた領上沈比べ変化のない領域の方が遙かに広く, 必要とする信号がそれにより覆われたととによる可能性 が高い。

Al 電極の場合のわずかなOの増加は, 前駆電流の影 響によりOを含むガスが吸着したか，あるいはそれによ り照射領域が酸化され $\mathrm{Al}_{2} \mathrm{O}_{3}$ となっているととを表し ているあのと考えられる。しかしながら，先に述べた分 析領域の広さによる影響も考えられるが， Al のピーク には化学シフトは確認されず，乙の○の増加について断 定的なととを述べるととは不可能である。また，電子照 射を行った場合に通常観測されるCの蓄積屯特に確認し 得なかった。

次に酸化 $\mathrm{Al}$ 電極についての表面分析結果を Fig.7 


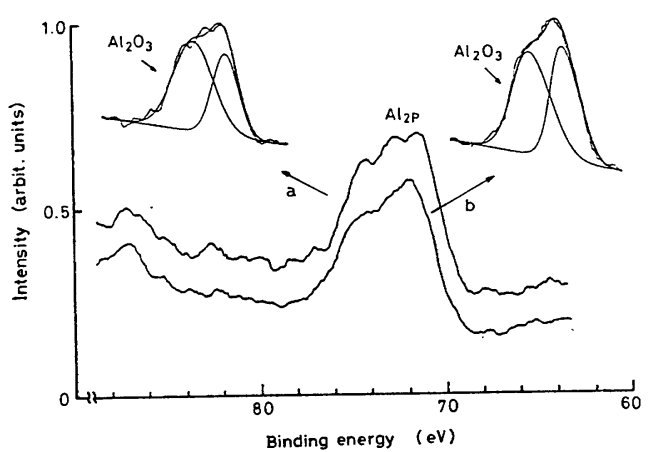

Fig. 7 Change in $\mathrm{Al}_{2 \mathrm{p} 3 / 2}$ line of the oxidized Al surface with electron bombardments by the electron gun.

に示す。この図は $\mathrm{Al}_{2 \mathrm{p} 3 / 2}$ のピークに波形分離操作を施 したあのであり, $\mathrm{Al}_{2} \mathrm{O}_{3}$ 生成により生ずる化学シフト のピークは減少しているととがわかる。先の正イオン分 析では $\mathrm{Al}_{2} \mathrm{O}_{3}$ の放出が確認されなかったととから，て の○の減少は $\mathrm{Al}_{2} \mathrm{O}_{3}$ 自体が脱離して減少したのではな く, 電子照射により分解され，Oとして放出されたか, あるいは化学反応により新たなガスとなって放出された 結果と考えられる。酸化電極の場合は, Al に限らず Cu の場合も Oが減少する結果が得られた。

このように，清浄な $\mathrm{Al}$ 電極の場合にはOが集積する のに対し, 酸化した場合には逆にOの放出が起きている ことは, 電子照射開始時の表面状態により陽極からのガ ス放出特性が変化することを意味している。従って, て のととは, 陽極表面状態が絶縁破壊に影響を及ぼす要因 の一つを実験的に示したものといえる。

電子照射により陽極表面状態が変化し, 各種のガスが 放出されるととが確認された。これらのガスのうちに は, 真空容器内に拡散するすのの他に, ギャップ間の空 間仪閉じ込如あのあある。それらは，陰極に入射 し, 陰極の表面状態を変化させ，電子放射特性に変化を 生じさせることが可能である。従って，陰極へのてれら のガスの吸着の確認及びそれによる表面状態変化の分析 が今後必要であり, それにより真空の絶縁破壊に及ぼす 電極表面状態の影響がより明確になるすのと期待でき る。しかしながら, この種の研究に有力な手段である XPS 法は分析領域の局所化が困難であり, 非破壊的に 局所領域の表面分析が行える手法の開発が待たれる。

\section{4. まとめ}

真空絶縁破壊前駆状態において，陽極から発生するイ オンについては飛行時間型質量分析法により, 中性ガス については 4 重極質量分析計により，更に，電子照射領 域を XPS 法により分析を行い，発生ガス成分と表面状 態変化との相関について検討を加えた。得られた成果は 以下のようにまとめることができる。

1）前駆状態での発生イオンは, 残留ガス成分と一致 する。

2）残留ガス成分の中には，前駆電流による電子照射 開始と同時に分圧が上昇する成分と減少する成分と がある。

3）それに対して, 電子銃による電子照射では残留ガ スのすべての成分の分圧が上昇した。

4）乙の電子照射により陽極表面状態には変化が見ら れ, A1 清浄面にはOが蓄積されるのに対し, 酸化 面では逆にOが減少する。このガス放出特性の相違 が真空の破壊現象を複雑にしている。

5）これらの結果から, 電子照射面では化学反応によ り新たなガス種が形成されている可能性があるとと が明らかとなった。

6）陽極から放出されたガスの陰極面への効果が述べ られ, 真空絶縁破壊現象解明の上で陰極面の分析の 必要性が指摘された。

\section{文献}

1) R. V. Latham: "High Voltage Vacuum Insulation: The Physical Basis" (Academic Press, London, 1981) p. 6.

2) G. A. Farrall : IEEE Trans. EI-20, 815 (1985).

3) L. Cranberg: J. Appl. Phys. 23, 518 (1952).

4) P. A. Chatterton: Proc. Phys. Soc. (London) 88, 231 (1966).

5) R. V. Latham : IEEE Trans. EI-23, 9 (1988).

6) V.A. Nevrovsky, V. I. Rakhovsky and Zhurbenko: Beitr. Plasmaphys. 23, 433 (1983).

7) K. Suzuki and S. Kobayashi: Jpn. J. Appl. Phys. 25, 1657 (1986).

8）小林信一, 鈴木憲司, 勝部昭明 : 表面科学 7, 142 (1986).

9) 鈴木憲司, 小林信一：真空 29, 495 (1986).

10) "Electron Spectroscopy for Surface Analysis", ed. by H. Ibach (Springer, Berlin, 1977) p. 20.

11) S. Kobayashi and K. Suzuki: J. Phys. D 19, 825 (1986). 